\title{
Global Intermediate-Good Price Stickiness and the Determinants of the Real Effects of Monetary and Government Spending Shocks
}

\author{
Yong-Yil Choi \\ Hansung University
}

\begin{abstract}
As industrialization and globalization are spread across the world, price competition is growing fierce in the final-good sector while many intermediate goods are enjoying global imperfect competition. Hence, when prices of intermediate goods are globally sticky in LCP (local-currency pricing) but consumer prices are flexible, the determinants of the short-run real effects of monetary and government spending shocks are explored in an open economy model with labor market inefficiency and global sourcing. Major findings are as follows: first, in the presence of a structural inefficiency in labor market, monetary and government spending shocks have ambiguous effects on the demand for domestic intermediate goods; second, even if there is price stickiness in the intermediate-good sector, monetary and government spending shocks may not affect final output in the short run; third, the natural rate of unemployment, the natural rate of productivity growth, and the trade-off between unemployment and inflation play a key role for exchange rate changes to bring forth beneficial real effects.
\end{abstract}

- JEL Classifications: F12, F41, F42

- Key words: intermediate-good price stickiness, real effects, money shock, government spending shock, the new open-economy macro model

\footnotetext{
*Corresponding address: Yong-Yil Choi, Professor, Department of International Trade, Hansung University, 3389 Samseon-dong, Seongbuk-gu, Seoul 136-792, Korea, Tel: +82-31-703-0956, +82-2-760-4386, Email: yychoi8@unitel.co.kr (C2005-Center for International Economics, Sejong Institution, All Rights Reserved.
} 


\section{Introduction}

Recently, as globalization becomes a trend, global imperfect competition is growing. The event such as Micron Technology's attempt to acquire Hynix or US Justice Department's investigation into the allegations of international semiconductor companies' price collusion illustrates the importance of this development vividly. It seems that anti-trust is becoming a typical issue of world economy.

One can expect that global imperfect competition will be deeper in the intermediate-good sector than in the final-good sector. Increasing competitive pressures due to the worldwide industrialization and globalization trend cause many firms to combine domestic and international sourcing while price competition is growing fierce in the final-good sector. As the relationship such as personal computer versus Intel chip or cellular phone versus CDMA chip indicates, firm's market power will depend heavily on whether the company can produce key components based on high technology. This tendency leads final-good prices to be flexible but intermediate-good prices to be rigid. In practice, many intermediate goods are supplied at fixed prices according to the contracts in the short run while nowadays many final-good dealers feel difficulties to sustain the local prices due to the penetration by global arbitrageurs such as parallel importers and re-importers.

This paper introduces a new open-economy model with involuntary unemployment and global sourcing where prices of intermediate goods are globally sticky with monopolistic competition but consumer prices are competitive and flexible. Then the determinants of the short-run real effects of monetary and government spending shocks are examined. Although there have been many models on openeconomy dynamic general equilibrium since the publication of Obstfeld and Rogoff(1995), this line of research is few, as shown in Lane(2001), Obstfeld(2001), Bowman and Doyle(2003) which provide a comprehensive survey on 'the new open-economy macro model'.

This paper has three distinctive characteristics, compared with other researches. First, the model introduces a hybrid of two kinds of the short-run price change (i.e. flexible consumer prices and rigid intermediate-good prices). In general, there are two types of pricing assumption in the new open-economy macro models. One is the $\mathrm{PCP}$ (producer-currency pricing) model, where nominal prices are fixed in the producers' currencies, so that the prices for consumers change proportionally in the short run to changes in the nominal exchange rate(e.g. Obstfeld and Rogoff(1995), 
Obstfeld(2001)). The other is the LCP(local-currency pricing) model, where nominal prices are set in advance in the currency of consumers(e.g. Devereux (1997), Engel(2002)). However, as Campa and Goldberg(2002)'s evidence of the short-run partial pass-through in the 25 OECD countries suggests, the hybrid of PCP and LCP seems to be more realistic. Thus, the LCP in intermediate good prices of this paper makes nominal exchange rate changes indirectly affect intermediate good demand through flexible consumer prices while nominal exchange rate changes directly affect intermediate good demand in Obstfeld (2001)'s PCP setting.

Second, this paper adopts formally the structure of global sourcing in intermediate goods, so the channel of intermediate-good trade plays a clear role in the transmission of macro shocks. This leads to modify the result of the model simply introducing imperfect competition and nominal rigidities such that a monetary expansion increases output and employment but it has no effect on price level in the short run. Hence, this specification helps to place global price stickiness relevantly on the short-run real effects of monetary and government spending shocks.

Third, the model incorporates involuntary unemployment induced by intermediategood price stickiness. It treats explicitly the external effects of nominal rigidities on labor market. Thus, the labor market structure in this model contrasts with the existing literature building on the work by Obstfeld and Rogoff(1995), so that the trade-off between unemployment and inflation plays a role in the short-run real effects of monetary and government spending shocks.

Therefore, in Section 2 this paper builds a flexible-price open economy model with incomplete capital market and global sourcing where differentiated intermediate goods are produced under monopolistic competition, and final goods are competitively produced using less-skilled labor and varieties of intermediate goods. Section 3 introduces global intermediate-good price stickiness and labor market inefficiency, and then examines the short-run real effects of monetary and government spending shocks on intermediate-good demand and final output. The results show that a triple combination of the sticky price power parameter, the structural parameters representing labor market inefficiency, and the adjustment power of other flexible prices decides the real effects of monetary and government spending shocks. Section 4 concludes with major findings. 


\section{The Basic Model with Flexible Prices}

Suppose the world consists of two countries. Two countries have identical preferences and production conditions. Each economy has two sectors: the sector of final goods and the sector of intermediate goods. The final good sector is competitive while the intermediate good sector is monopolistically competitive. Assume free trade in both final goods and differentiated intermediate goods, but no migration of labor.

Suppose goods are produced in a Ricardian structure. There are two factors of production: the intermediate good sector-specific labor $\left(L_{s}\right)$, and the final good sector-specific labor $\left(L_{m}\right)$. Assume that labor supply is exogenous, and the intermediate-good sector-specific labor is more skilled than the final-good sectorspecific labor. We can explain the latter assumption as follows: since monopolistic competition is assumed in the intermediate-good sector, the product of that sector has a market power; it is usual for skilled labor to have a market premium and thus to be specific to that sector (e.g. computer-chip designers vs. computer-assemblyline workers). The growth rate of the final-good sector-specific labor is $\mathrm{m}_{\mathrm{m}}$ and the growth rate of the intermediate-good sector-specific labor is $\mathrm{m}_{\mathrm{s}}$. The labor markets are competitive.

The final good $\mathrm{X}$ are competitively produced using not only the final-good sector-specific labor $\left(L_{m}\right)$, but also varieties of intermediate goods: $H_{i}, i=1, \cdots$, $\left(n+n_{f}\right)$, where $\mathrm{n}$ is a domestic variety and $\mathrm{n}_{\mathrm{f}}$ is a foreign variety.

Assuming an aggregate two-stage Cobb-Douglas-CES production function, the production function of the final good $\mathrm{X}$ takes the form,

$$
X=L_{m}{ }^{l-\alpha}\left(\Sigma_{i=1, \cdots, n+n f} H_{i}^{\beta}\right)^{\alpha / \beta} .
$$

If $\mathrm{H}_{\mathrm{i}} \mathrm{s}$ are the same for all $\mathrm{i}$ in the equation (1), $\left(\mathrm{n}+\mathrm{n}_{\mathrm{f}}\right)^{1 / \beta}$ represents skill-using technical change. It is assumed that

$$
\begin{gathered}
0<\beta<1 \text { and } 0<\alpha<1, \\
\beta=[1-(1 / \sigma)],
\end{gathered}
$$

where $\sigma=$ the constant elasticity of substitution among intermediate goods. Each country shares the common $\alpha$ and $\beta$. Thus, the value of $\beta$ shows the degree of substitutability among intermediate goods. The lower the $\beta$ is, the more differentiated the intermediate goods are, which induces the higher skill-using technical change for the final output. 
Differentiated intermediate goods are produced using only sector-specific labor $\left(L_{s}\right)$ under Chamberlinean monopolistic competition, so that the number of intermediate goods produced is large enough to make oligopolistic interaction negligible. There are increasing returns at the level of an individual firm. The production of the $i^{\text {th }}$ intermediate good, $H_{i}$, involves some fixed labor input requirements $\left(z_{o}\right)$ and variable labor input requirements $\left(z H_{i}\right)$ where $\mathrm{z}$ represents the constant marginal labor input requirements.

Suppose all firms in the sector of intermediate goods are symmetric. Thus, in equilibrium, all intermediate goods actually produced will be produced in the same quantity and at the same price.

Then, the home's competitive profit condition for the sector of final goods is given by

$$
P_{t}=k\left(n_{t}+n_{f, t}\right)^{-(\alpha / \beta)+\alpha} q_{t}^{\alpha} W_{m, t}^{1-\alpha},
$$

where $k=\alpha^{-\alpha}(1-\alpha)^{\alpha-1} ; P_{t}$ is the price of final goods $X$ on date $t ; q_{t}$ is the price of intermediate goods on date $t ; W_{m, t}$ is the wage rate for less-skilled labor on date $t$, and similarly for the foreign country.

The home country's condition for profit maximization in the intermediate goods sector is to equate marginal revenue to marginal cost, i.e.

$$
q_{t}[1-(1-\beta)]=W_{s, t} z,
$$

where $W_{s, t}$ is the wage rate for the intermediate-good sector-specific skilled labor on date $t$, and (1- $\beta$ ) is in absolute value the elasticity of the inverse demand for intermediate goods, and similarly for the foreign country.

Since free entry is assumed, any non-zero profit will be eliminated and in equilibrium holds the following

$$
q_{t} H_{t}=\left(z_{o}+z H_{t}\right) W_{s, t}
$$

and similarly for the foreign country.

The less skilled and skilled labor market clearing condition are given, respectively, by

$$
\begin{gathered}
k(1-\alpha)\left(n_{t}+n_{f, t}\right)^{-(\alpha \beta \beta)+\alpha} q_{t}^{\alpha} W_{m, t}{ }^{-\alpha} X_{t}=L_{m}^{o}\left(1+m_{m, t}\right) \\
n_{t}\left(z_{o}+z H_{t}\right)=L_{s}^{o}\left(1+m_{s, t}\right)
\end{gathered}
$$


where $L_{m}{ }^{o}$ is the endowment of less-skilled labor; $L_{t s}{ }^{o}$ is the endowment of skilled labor; $m_{m, t}$ is the growth rate of less-skilled labor on date $t ; m_{s, t}$ is the growth rate of skilled labor on date $t$, and similarly for the foreign country.

Since prices are flexible and preferences and technology are identical across countries, purchasing power parity holds:

$$
\begin{aligned}
P_{t} & =\varepsilon_{t} P_{f, t}{ }^{*}, \\
q_{t} & =\varepsilon_{t} q_{f, t}{ }^{*},
\end{aligned}
$$

where $\varepsilon_{t}$ is the nominal exchange rate(the home-currency price of foreign currency) on date $t$; the subscript ' $f$ ' denotes the foreign variable; and the superscript '*' indicates price in the foreign currency.

Assume that the household's utility function depends positively on consumption and real balances; the government issues no interest-bearing debt and holds no interest-bearing assets. As in Obstfeld and Rogoff(1995), the only asset both countries trade is a real bond, denominated in the final output. Namely, the lifetime utility maximization subject to the period budget constraint is written as:

$$
\begin{aligned}
& \operatorname{Max} U_{t}=\sum_{s=t}^{\infty} \delta^{s-t}\left[\log C_{s}+\theta \log \left(\frac{M_{s}}{P_{s}}\right)\right] \\
& \text { s.t } P_{t} B_{t+1}+M_{t}=P_{t}\left(1+r_{t}\right) B_{t}+M_{t-1}+Y_{t}(1-\tau)-P_{t} C_{t},
\end{aligned}
$$

where

$$
\begin{aligned}
& Y_{t}=W_{m, t} L_{m}^{o}\left(1+m_{m, t}\right)+W_{s, t} L_{s}^{o}\left(1+m_{s, t}\right), \\
& 0<\delta<1 \text { and } \theta>0,
\end{aligned}
$$

and similarly for the foreign country.

In the above maximization, $\delta$ is a discount factor; $C_{t}$ is real consumption expenditure on date $t ; M_{t}$ is the quantity of nominal money balances accumulated during period $\mathrm{t}$ and carried over into period $t+1$; $\mathrm{B}$ denotes the net private holdings of bonds issued by foreigners, which are denominated in the final output; $r_{t}$ denotes the real interest rate on bonds between $t-1$ and $t ; Y_{t}$ is total household income on date $t ; \tau$ is a flat income tax rate. The foreign country shares the common $\delta$ and $\theta$. Since the only asset both countries trade is a real bond, they face the common real interest rate.

By solving the problem of preference maximization, the first order conditions are derived as follows: 


$$
\begin{gathered}
\delta\left(1+r_{t+1}\right) C_{t}=C_{t+1}, \\
M_{t} / P_{t}=\theta C_{t}\left(1+i_{t+1}\right) / i_{t+1},
\end{gathered}
$$

where $i_{t+1}$ in the nominal interest rate between $t$ and $t+1$. Equation (11) is the standard consumption Euler equation. Equation (12) is the money market equilibrium condition.

To simplify, assume that all government purchases are financed by tax and seigniorage:

$$
G_{t}=\left(\tau Y_{t} / P_{t}\right)+\left(M_{t}-M_{t-1}\right) / P_{t}
$$

where $G_{t}$ is real government consumption expenditure. Analogous equation holds for the foreign country.

The home usage of each intermediate good is derived as

$$
H_{d, t}=k \alpha\left(n_{t}+n_{f, t}\right)^{-(\alpha / \beta)+\alpha-1} q_{t}^{\alpha-1} W_{m, t}{ }^{1-\alpha}{ }_{.}
$$

The world market clearing condition for intermediate goods is

$$
\left(n_{t}+n_{f, t}\right) H_{d, t}+\left(n_{t}+n_{f, t}\right) H_{d, t}^{f}=\left(n_{t}+n_{f, t}\right) H_{t},
$$

where $n_{f, t}=$ the number of foreign intermediate goods on date $t ; H_{d, t}{ }^{f}=$ the foreign usage of each intermediate good on date $t$.

\section{The Effects of Monetary and Government Spending Shocks with Global Intermediate-Good Price Stickiness and Labor Market Inefficiency}

I now introduce global intermediate-good price stickiness in the basic model of Section 2. In the short run, nominal intermediate-good prices, $\mathrm{q}$ and $\mathrm{q}_{\mathrm{f}}$, are set a period in advance as $q^{o}$ and $q_{f}^{o}$ respectively, but they can be adjusted fully after one period. Here, both $q^{o}$ and $q_{f}^{o}$ are predetermined in local-currency pricing. Consumer prices are still flexible due to perfect competition. This setting is a hybrid of PCP in final goods and LCP in intermediate goods. It reflects the trend of the global sourcing in intermediate goods and the worldwide competition in final goods, as mentioned in the introduction. 
With the nominal rigidity of intermediate-good prices the long-run zero profit condition (4) and the purchasing power parity condition (8) of the intermediate good sector do not hold. Since $q^{o}$ and $q_{f}^{o}$ are the predetermined intermediate-good prices, in the short run, the competitive profit condition (2) changes as follows:

$$
P_{t}=k\left(n_{t}+n_{f, t}\right)^{-(\alpha / \beta)}\left(n_{t} q^{o}+n_{f, t} q_{f}^{o}\right)^{\alpha} W_{m, t}{ }^{1-\alpha}
$$

Suppose rigid intermediate-good prices induce unemployment in the final good sector. We can explain this as follows: with the market power of the intermediate good sector a rigid intermediate-good prices affect the labor productivity of the final good sector, playing a kind of technology shock; this externality reduces the demand for less-skilled labor. Hereby, the rigidity of intermediate-good prices affects consumer prices and the final-good sector wages, and thus with natural rates of unemployment and productivity growth the unemployment rate at $t$ can be expressed by the following equation:

$$
U_{m, t}=U^{*}+\rho_{m}\left[\left(W_{m, t+I^{-}}-W_{m, t}\right) / W_{m, t}-\left(P_{t+1}-P_{t}\right) / P_{t}-\phi\right],
$$

where $\mathrm{U}^{*}$ is a natural rate of unemployment; $\phi$ is a natural rate of productivity growth. The analogous equation holds for the foreign country. Eq. (17) says that the unemployment gap is linearly approximated by excess real wage inflation above the natural rate. The trade-off relationship between unemployment gap and excess real wage inflation implies $\rho_{m}<0$. For simplicity, it is assumed that each country faces the same $\mathrm{U}^{*}, \phi$ and $\rho_{m}$.

Therefore, the less-skilled labor market clearing condition (5) and the home usage of each intermediate good (14) change as follows:

$$
\begin{gathered}
k(1-\alpha)\left(n_{t}+n_{f, t}\right)^{-(\alpha \beta \beta)}\left(n_{t} q^{o}+n_{f, t} q_{f}^{o}\right)^{\alpha} W_{m, t}{ }^{-\alpha} X_{t}=L_{m}^{o}\left(1+m_{m, t}\right)\left(1-U_{m, t}\right) \\
H_{d, t}=k \alpha\left(n_{t}+n_{f, t}\right)^{-(\alpha / \beta)}\left(n_{t} q^{o}+n_{f, t} q_{f}^{o}\right)^{\alpha-1} W_{m, t}^{1-\alpha_{t} .}
\end{gathered}
$$

Also, eq. (3) doesn't hold in the short run, because the rigid nominal intermediategood prices $q^{o}$ and $q_{f}^{o}$ set the wage rate for the skilled labor in advance as $W_{s}^{\mathrm{o}}$ and $W_{s, f}{ }^{\circ}$ by the predetermined marginal revenue from the sale of intermediate goods. Thus, the total household nominal-income equation (10) changes as follows:

$$
Y_{t}=W_{m, t} L_{m}^{o}\left(1+m_{m, t}\right)\left(1-U_{m, t}\right)+W_{s}^{o} L_{s}^{o}\left(1+m_{s, t}\right)
$$


The remaining equations (6), (7), (9), (11), (12), (13), and (15) hold with the global intermediate-good price stickiness

As in Obstfeld and Rogoff(1995), the world economy reaches a steady state after one period. In the steady state, since prices and exchange rate are fully flexible, the unemployment gap is minimized, and the law of one price holds world widely. Thus, the short run deviation from the steady state implies a nonoptimality; the real effects of macroeconomic policy are expected.

The Appendix provides the symmetric steady state. Log-linearizing the model around the initial symmetric steady state makes it possible to express the short run deviations from the baseline steady-state path. Since the world economy reaches its new steady-state after a single period, we can replace all $(t+1)$-subscripted variables in the linearized equations with steady-state changes. All t-subscripted variables are regarded as short-run values. Denote the short-run percentage changes from the baseline steady-state path by hated variables without time-subscripts or overbars; thus, for any variable, $\hat{X} \equiv d X / \bar{X}_{o}$, where $\bar{X}_{o}$ is the initial steady-state value.

(1) Effects on Intermediate-Good Demand Changes

To examine the effects of monetary and government spending shocks on intermediate-good demand changes, we derive first the short-run percentage change in final-good prices from (11), (12), and the Appendix's (A9):

$$
\hat{P}=\hat{M}-\hat{C}=\hat{M}-\left(\frac{1-\tau}{\tau}\right)\left(\frac{d \bar{G}}{\bar{C}}\right)
$$

By symmetry, adding the subscript ' $f$ ' to the variables in (21) implies the corresponding equation for the foreign country.

Using (7) and (21), we can express the short run exchange rate change as

$$
\hat{\varepsilon}=\hat{M}-\hat{M}_{f}-\left(\frac{1-\tau}{\tau}\right)\left[\frac{d \bar{G}}{\bar{C}}-\frac{d \bar{G}_{f}}{\bar{C}_{f}}\right]
$$

(21) and (22) show that a permanent unanticipated money supply increase causes proportionate increases in consumer prices and exchange rate. Thus, exchange rate overshooting like Dornbusch(1976)'s does not occur in this model. This result is similar to Obstfeld and Rogoff(1995)'s. Although consumer prices and exchange rate change in proportion to a money shock, with global intermediate-good price stickiness exchange rate change affects not directly but 
indirectly the relative prices of intermediate-goods, $q^{\mathrm{o}} / P$ and $q_{f}^{\mathrm{o}} / P$, through consumer price change. Thus, exchange rate fluctuations have indirect impacts on demand for intermediate goods in this paper while Obstfeld(2001), where intermediate goods are produced in perfect competition and have PCP, shows that exchange rate fluctuations have direct re-allocative effects at the level of traded inputs used by firms in producing consumer goods.

When global intermediate-good price stickiness exists, the transmission channels of monetary and government spending impacts are as follows: first, the shocks affect consumer prices, exchange rate, and trade in intermediate goods; in turn, nominal wage rate changes; finally, employment and output are affected. To show this connection, using $\bar{W}_{m}=\bar{P}$ from (17), we can express the short-run relationship between unemployment change and real wage rate change as

$$
\hat{U}_{m}=\left(\frac{\rho_{m}}{\bar{U}_{m}}\right)\left(\hat{P}-\hat{W}_{m}\right)
$$

Suppose the supply of skilled labor is fixed in the short run, namely $\hat{m}_{s}=\hat{m}_{s, f}=0$. This implies $\hat{n}=\hat{n}_{f}$. Then, using (18), (19), (23), (16), (6), and (15), we can get the following intermediate-good demand change:

$$
\hat{H}_{d}=A \hat{P}+\left(\frac{\frac{\alpha}{\beta}\left(1-\bar{U}_{m}+\rho_{m}\right)-\alpha \rho_{m}-\left(1-\bar{U}_{m}\right)}{(1-\alpha)\left(1-\bar{U}_{m}\right)}\right) \hat{n}
$$

where $A \equiv \frac{\alpha \rho_{m}+\left(1-\bar{U}_{m}\right)}{(1-\alpha)\left(1-\bar{U}_{m}\right)}$

The equation (24) shows that the short run change in domestic demand for each intermediate good is related to domestic inflation and change in the number of intermediate goods reflecting trade in intermediate goods. The trade-off relationship between demand for each intermediate good and the number of intermediate goods causes the bracket term in (24) to have negative sign. Equation (24) represents the mechanism such that money and government spending shocks affect the channel of inflation-exchange rate-intermediate good trade, and in turn, demand for intermediate-good changes. To see this, expressing (24) in terms of inflation and exchange rate change, we can get

$$
\hat{H}_{d}=\left(\frac{1}{1-\beta}\right) \hat{P}+\left(\frac{1}{1-\beta}\right) D \bar{H}_{d, f} \hat{\varepsilon}
$$


where $D \equiv\left(\frac{\frac{\alpha}{\beta}\left(1-\bar{U}_{m}+\rho_{m}\right)-\alpha \rho_{m}-\left(1-\bar{U}_{m}\right)}{(1-\alpha)\left(1-\bar{U}_{m}\right)}\right)\left(\frac{z}{z_{o}+z \bar{H}}\right)$.

As shown in (24)', although money shock causes proportionate changes in exchange rate and consumer price level, the impacts of the same extent of inflation and exchange rate change on demand for intermediate goods are different each other. This is because exchange rate change affects demand for intermediate goods indirectly through changes in the number of intermediate goods, in contrast to other models with trade in final goods. To examine this, we can reduce (24)' to be

$$
\hat{H}_{d}=\left[\frac{1}{1-\beta}\left(1+D \bar{H}_{d, f}\right)\right]\left[\hat{M}^{-}\left(\frac{1-\tau}{\tau}\right)\left(\frac{d \bar{G}}{\bar{C}}\right)\right]-\left(\frac{1}{1-\beta}\right) D \bar{H}_{d, f}\left[\hat{M}_{f}-\left(\frac{1-\tau}{\tau}\right)\left(\frac{d \bar{G}_{f}}{\bar{C}_{f}}\right)\right]
$$

In (25), D $<0$ from the trade-off relationship between demand for each intermediate good and the number of intermediate goods. But the impacts of home monetary and government spending shock on domestic demand for intermediate goods depend on the sign of $\left(1-\bar{U}_{m}+\rho_{m}\right)$. That is,

since $\left(1+D \bar{H}_{d, f}\right)=\frac{\alpha}{1-\alpha} \frac{1-\beta}{\beta}\left(\frac{1-\bar{U}_{m}+\rho_{m}}{1-\bar{U}_{m}}\right) \frac{z \bar{H}_{d, f}}{z_{o}+z \bar{H}}+\frac{z_{o}+z \bar{H}_{d}}{z_{o}+z \bar{H}}$,

$\left(1+D \bar{H}_{d, f}\right)>0$ under $\left(1-\bar{U}_{m}+\rho_{m}\right) \geq 0$. If $\left(1-\bar{U}_{m}+\rho_{m}\right)<0$, then the sign of $\left(1+D \bar{H}_{d, f}\right)$ is ambiguous.

As (Table 1) summarizes the results, if $\left(1-\bar{U}_{m}+\rho_{m}\right) \geq 0$, home and foreign money shocks have a positive impact on domestic demand for intermediate goods, while home and foreign government spending shocks have a negative impact on the demand. However, the sizes of impact differ in both cases of $\left(1-\bar{U}_{m}+\rho_{m}\right)>0$ and $\left(1-\bar{U}_{m}+\rho_{m}\right)=0$. For example, home money and government spending shocks have a larger impact in the case $\left(1-\bar{U}_{m}+\rho_{m}\right)>0$ than that in the case $\left(1-\bar{U}_{m}+\rho_{m}\right)=0$. This is because the labor market is structurally less inefficient under $\left(1-\bar{U}_{m}+\rho_{m}\right)>0$ relative to the case of $\left(1-\bar{U}_{m}+\rho_{m}\right)=0$.

The condition $\left(1-\bar{U}_{m}+\rho_{m}\right.$ ) playing a key role in (25) is the sum of a steadystate employment rate minimizing unemployment gap (see Appendix A6) and a trade-off between unemployment and inflation. Since $\bar{U}_{m}=U^{*}-\rho_{m} \phi$ in the 
steady state, $\left(1-\bar{U}_{m}+\rho_{m}\right)=0$ means that the natural rate of employment (1-U*) equals $-\rho_{m}(1+\phi) \cdot\left(1-\bar{U}_{m}+\rho_{m}\right)>0$ implies that $\left(1-\mathrm{U}^{*}\right)>-\rho_{m}(1+\phi)$, while $\left(1-\bar{U}_{m}+\rho_{m}\right)<0$ implies that $\left(1-U^{*}\right)<-\rho_{m}(1+\phi)$. This suggests that the labor market having a larger value of the natural rate of employment should be a structurally less inefficient one. Thus, the labor market with $\left(1-\bar{U}_{m}+\rho_{m}\right)>0$ is structurally less inefficient than that of $\left(1-\bar{U}_{m}+\rho_{m}\right)=0$. The labor market with $\left(1-\bar{U}_{m}+\rho_{m}\right)=0$ is structurally less inefficient relative to the case of $\left(1-\bar{U}_{m}+\rho_{m}\right)<0$.

We know that the absolute value of $\rho_{\mathrm{m}}$ plays a threshold role in (25). The actual value of $\rho_{\mathrm{m}}$ depends on the economy itself. For example, Phillips (1958)'s estimate (p. 287) indicates $\rho_{m}=-0.717$. From the actual data of the natural rate of unemployment $\left(\mathrm{U}^{*}\right)$, the trade-off between unemployment and inflation $\left(\rho_{\mathrm{m}}\right)$, and the natural rate of productivity growth $(\phi)$, we can estimate the sign of $\left(1-\bar{U}_{m}+\rho_{m}\right)$.

Under $\left(1-\bar{U}_{m}+\rho_{m}\right) \geq 0$ home money-supply increase causes domestic intermediate-good demand increase in the short run, because relative prices of intermediate goods, $q^{o} / P$ and $q_{f}^{o} / P$, decline as consumer prices rise due to money supply increase but intermediate-good prices are fixed with LCP. Under the same condition home government spending increase results in domestic intermediategoods demand decrease, because relative prices of intermediate goods rise as consumer prices decline.

On the other hand, if $\left(1-\bar{U}_{m}+\rho_{m}\right)<0$, then the impacts of home monetary and government spending shocks on domestic intermediate-good demand are ambiguous. This implies that it is difficult to control domestic intermediate-good demand in the short run by macroeconomic policies. The uncertainty in demand for intermediate goods comes from two sources: first, exchange rate change adjusts terms of trade incompletely with intermediate-good prices fixed in LCP; second, the structural inefficiency of labor market causes consumer price adjustment through exchange rate change to be uncertain. Of course, as Engel (2002) claims, this uncertainty will disappear with fixed exchange rate system. Engel (2002), which introduces Devereux, Engel, and Tille(1999)'s new version, concludes that if a large degree of elasticity of substitution between imports and locally produced goods(as in the Obstfeld(2001) model) occurs, then exchange-rate flexibility is desirable. In contrast my model shows that exchange rate fluctuations make demand for intermediate-goods unpredictable due to the structural inefficiency in labor market, so that the effects of monetary and fiscal shocks are uncertain. Therefore, we can conclude that the value of $\left(1-\bar{U}_{m}+\rho_{m}\right)$ is a threshold for 
exchange rate changes to play a beneficial role.

However, the impacts of foreign monetary and government spending shocks on domestic intermediate-goods demand are certain. This is because the influences of the foreign shocks come through not domestic consumer price change but foreign consumer price $\left(P_{f}{ }^{*}\right)$ change. Namely, foreign money shock has a positive association with domestic intermediate-goods demand, while foreign government spending shock is negatively associated with it.

The short run relative prices of intermediate goods $\left(q^{o} / \varepsilon P_{f}^{*}\right.$ and $\left.q_{f}^{o} / \varepsilon P_{f}^{*}\right)$ do not change as foreign money supply increases, because the change of $\varepsilon$ by foreign money supply increase is offset by the change of $\mathrm{P}_{\mathrm{f}}{ }^{*}$. Thus, the rise in the domestic intermediate-good demand due to foreign money supply increase, as (24)' and (25) indicates, occurs through the channel of the number of intermediate-good change: foreign money supply increase causes home currency to appreciate; the home currency appreciation reduces the world demand for home final goods but initially can't affect the demand for home intermediate goods due to the unchanged shortrun relative prices of intermediate goods; this expenditure switching leads to the reduction of the number of intermediate goods; in the end, the reduction of the number of intermediate goods due to foreign money supply increase causes the domestic demand for intermediate goods to rise. The opposite is true for the decrease in the domestic intermediate-good demand by foreign government spending increase.

(2) Effects on Final Output Changes

To show the effects of monetary and government spending shocks on final output changes, first, using (16) and (25), we derive the relationship between the short-run nominal wage rate change of less-skilled labor and inflation as follows:

$$
\hat{W}_{m}=\frac{1}{1-\alpha}\left(1-\Omega \bar{H}_{d}\right) \hat{p}-\frac{1}{1-\alpha} \Omega \bar{H}_{d, f} \hat{p}_{f}^{*}
$$

where $\Omega \equiv \alpha\left(\frac{1-\beta}{\beta}\right)\left(\frac{z}{z_{o}}\right)$.

Since $\Omega=\frac{\alpha}{\bar{H}}$, from (26) we know that the rate of change in nominal wages has a positive association with domestic inflation. But the impact of exchange rate change on the final-good sector nominal wage-rate change is muted by the symmetry assumption in this model, which implies exchange rate change does not disturb the short-run unemployment change.

Under the assumption of $\hat{m}_{s}=\hat{m}_{s, f}=0$, using (19), (26), and (21), we can get 
the short-run domestic final output change as follows:

$$
\hat{X}=\frac{1}{1-\beta} D \bar{H}_{d, f} \hat{\varepsilon}+\frac{1}{1-\beta}\left(\frac{z_{o}+z \bar{H}_{d, f}}{z_{o}+z \bar{H}}\right) \hat{P}-\hat{P}-\frac{1}{1-\beta}\left(\frac{z \bar{H}_{d, f}}{z_{o}+z \bar{H}}\right) \hat{P}_{f}^{*}
$$

The coefficient $\frac{1}{1-\beta}$ was the elasticity of demand for intermediate goods in the flexible price model of the Section 2, but functions as a sticky-price power parameter in (27). The $D \bar{H}_{d, f}$ in the first term of (27) is a coefficient reflecting the influence of exchange rate change; the $\frac{z_{o}+z \bar{H}_{d, f}}{z+z \bar{H}}$ is a response coefficient to domestic inflation; the third term $-\hat{P}$ comes from nominal wage rate change. Therefore, we can infer that the real effects of monetary and government spending shocks are the net effects of the structural inefficiency of labor market, the adjustment power of exchange rate-consumer prices-nominal wage rate change, and the degree of price stickiness. Equation (27) can be rearranged as

$$
\begin{gathered}
\hat{X}=\left[\frac{\alpha}{1-\alpha} \frac{1-\beta}{\beta}\left(\frac{1-\bar{U}_{m}+\rho_{m}}{1-\bar{U}_{m}}\right) \frac{z \bar{H}_{d, f}}{z_{o}}\right]\left[\hat{M}-\left(\frac{1-\tau}{\tau}\right) \frac{d \bar{G}}{\bar{G}}\right] \\
-\left[\frac{\alpha}{1-\alpha} \frac{1-\beta}{\beta}\left(\frac{1-\bar{U}_{m}+\rho_{m}}{1-\bar{U}_{m}}\right) \frac{z \bar{H}_{d, f}}{z_{o}}\right]\left[\hat{M}_{f}-\left(\frac{1-\tau}{\tau}\right) \frac{d \bar{G}_{f}}{\bar{G}_{f}}\right]
\end{gathered}
$$

As shown in (28), the impacts of monetary and government spending shocks on final output change depend greatly on the value of $\left(1-\bar{U}_{m}+\rho_{m}\right)$, too. In particular, unlike Obstfeld(2001), the impact of money shocks on final output change is different, depending on the value of $\left(1-\bar{U}_{m}+\rho_{m}\right)$. Under $\left(1-\bar{U}_{m}+\rho_{m}\right)>0$ domestic final output rises as home money supply increases; under $\left(1-\bar{U}_{m}+\rho_{m}\right)<0$ the opposite effect occurs; under $\left(1-\bar{U}_{m}+\rho_{m}\right)=0$ the effect of money supply on final output is neutral (see Table 1).

This short-run neutrality under $\left(1-\bar{U}_{m}+\rho_{m}\right)=0$ implies that if the optimal employment rate $\left(1-U^{*}+\rho_{m} \phi\right)$ equals the absolute value of $\rho_{m}$, then monetary and government spending shocks can't affect real national income in the short run. The phenomenon that the effect of the sticky-price power parameter $\frac{1}{1-\beta}$ vanishes under $\left(1-\bar{U}_{m}+\rho_{m}\right)=0$ is clearly revealed in (28). That is, as (27) indicates, the effect of intermediate-good price stickiness is completely nullified by the adjustments of exchange rate, consumer prices, and nominal wage rate. So, the 
reason that under the same condition demand for intermediate goods and unemployment rate are not neutral to money and government spending shocks lies in the incomplete adjustments of exchange rate, consumer prices, and nominal wage rate.

Therefore, the above analysis shows that global intermediate-good price stickiness alone does not guarantee the existence of the short-run real effects of monetary and government spending shocks, but a combination of the sticky-price power parameter, the structural parameters representing labor market inefficiency, and the adjustment power of other flexible prices decides the real effects. In other words, global intermediate-good price stickiness, the adjustment power of other flexible price variables, and the deep parameters---the natural rate of unemployment $\left(U^{*}\right)$, the trade-off between unemployment and inflation $\left(\rho_{m}\right)$, and the natural rate of productivity growth $(\phi)$---yield the different real effects of monetary and government spending shocks in combination. Since the combination of the sticky price power parameter, the structural parameters representing labor market inefficiency, and the adjustment power of other flexible prices is a key factor of aggregate demand variability, from this result we can put a new interpretation on Lucas(1973), Ball, Mankiw, and D. Romer(1988)'s finding that nominal shocks have smaller real effects in settings where aggregate demand is more volatile.

\section{Conclusion}

This paper has provided an open economy model with incomplete capital market and global sourcing where differentiated intermediate goods are produced

Table 1. Effects of monetary and government spending shocks with global intermediategood price stickiness

\begin{tabular}{cccccc}
\hline Effects & Shocks & $\hat{M}$ & $\hat{M}_{f}$ & $\hat{\bar{G}}$ & $\hat{\bar{G}}_{f}$ \\
\hline \multirow{3}{*}{$\hat{H}_{d}$} & $\left(1-\bar{U}_{m}+\rho_{m}\right)>0$ case & + & + & - & - \\
& $\left(1-\bar{U}_{m}+\rho_{m}\right)<0$ case & Ambiguous & + & Ambiguous & - \\
& $\left(1-\bar{U}_{m}+\rho_{m}\right)=0$ case & + & + & - & - \\
$\hat{X} \hat{X}$ & $\left(1-\bar{U}_{m}+\rho_{m}\right)>0$ case & + & - & - & + \\
& $\left(1-\bar{U}_{m}+\rho_{m}\right)<0$ case & - & + & + & - \\
& $\left(1-\bar{U}_{m}+\rho_{m}\right)=0$ case & 0 & 0 & 0 & 0 \\
\hline
\end{tabular}

Notes: "+" indicates positive association; "-" denotes negative association; " 0 " means neutrality 
under monopolistic competition, and final goods are competitively produced using less-skilled labor and varieties of intermediate goods. The closed form solutions reveal the determinants of the short-run real effects of monetary and government spending shocks under global intermediate-good price stickiness in the LCP and labor market inefficiency.

One of the major findings is that if there exists a structural inefficiency in labor market, then the effects of home monetary and government spending shock on domestic intermediate-good demand changes are uncertain with global intermediate-good price stickiness. This implies that it is difficult to control domestic intermediate-good demand by macroeconomic policies in the short run. Second, the impacts of monetary and government spending shocks on final output change also depend greatly on the extent of the structural inefficiency in labor market. If the optimal employment rate equals the absolute value of the trade-off between unemployment and inflation, then the effects of monetary and government-spending shocks on final output change are neutral in spite of global intermediate-good price stickiness, which implies money and government spending shocks can't affect real national income in the short run. Third, the natural rate of unemployment, the natural rate of productivity growth, and the trade-off between unemployment and inflation play a key role for exchange rate changes to bring forth beneficial real effects.

Therefore, this paper shows that a triple combination of the sticky price power parameter, the structural parameters representing labor market inefficiency, and the adjustment power of other flexible prices decides the real effects of monetary and government spending shocks.

\section{Acknowledgements}

This research was financially supported by Hansung University in the year of 2005.

Received 16 September 2003, Accepted 23 April 2004

\section{References}

Ball, Lawrence, Mankiw, N. Gregory, and David Romer, "The New Keynesian Economics and the Output-Inflation Tradeoff," Brookings Papers on Economic 
Activity 19 (1988): 1-65.

Bowman, David and Brian Doyle, "New Keynesian Open-Economy Models and Their Implications for Monetary Policy," Board of Governors of the Federal Reserve Systems, International Finance Discussion Papers Number 762(2003).

Campa, Jose M. and Linda S. Goldberg, "Exchange Rate Pass-Through into Import Prices: A Macro or Micro Phenomenon?" Federal Reserve Bank of New York Discussion Paper(2002).

Devereux, Michael B., "Real Exchange Rates and Macroeconomics: Evidence and Theory," Canadian Journal of Economics 30 (1997): 773-808.

Devereux, Michael B., Charles Engle, and Cedric Tille, "Exchange Rate Pass-Through and the Welfare Effects of Euro," NBER Working Paper 7382(1999).

Dornbusch, Rudiger, "Expectations and Exchange Rate Dynamics," Journal of Political Economy 84 (1976): 1161-76.

Engle, Charles, "The Responsiveness of Consumer Prices to Exchange Rates and the Implications for Exchange Rate Policy: A Survey of a Few Recent New OpenEconomy Macro Models," NBER Working Paper 8725 (2002).

Lane, Philip R., "The New Open Economy Macroeconomics: A Survey," Journal of International Economics 54 (2001): 235-266.

Lucas, Robert E., Jr., "Some International Evidence on Output-Inflation Tradeoffs," American Economic Review 63 (1973): 326-334.

Obstfeld, Maurice, "International Macroeconomics: Beyond the Mundell-Fleming Model,” NBER Working Paper 8369 (2001).

Obstfeld, Maurice, and Kenneth Rogoff, "Exchange Rate Dynamics Redux," Journal of Political Economy 103 (1995): 624-60.

Phillips, A. W., "The Relationship between Unemployment and the Rate of Change of Money Wages in the United Kingdom, 1861-1957," Economica 25(1958): 283-299. 


\section{Appendix}

\section{A Symmetric Steady State}

From the model, we can get the following steady state equilibrium conditions for the home country. The bar notation indicates a steady state value of the corresponding variable.

$$
\begin{aligned}
& \bar{p}=k\left(\bar{n}+\bar{n}_{f}\right)^{-\frac{\alpha}{\beta}+\alpha} \bar{q}^{\alpha} \bar{w}_{m}^{1-\alpha} \\
& \bar{q} \beta=\bar{w}_{s} z \\
& \bar{q} \bar{H}=\left(z_{o}+z \bar{H}\right) \bar{w}_{s} \\
& k(1-\alpha)\left(\bar{n}+\bar{n}_{f}\right)^{-\frac{\alpha}{\beta}+\alpha} \bar{q}^{\alpha} \bar{w}_{m}^{-\alpha} \bar{X}=L_{m}^{o}\left(1+\bar{m}_{m}\right)\left(1-\bar{U}_{m}\right) \\
& \bar{n}\left(z_{o}+z \bar{H}\right)=L_{s}^{o}\left(1+\bar{m}_{s}\right) \\
& U_{m}=U^{*}-\rho_{m} \phi \\
& \bar{p}=\bar{\varepsilon} \bar{p}_{f}^{*} \\
& \bar{q}=\bar{\varepsilon} \bar{p}_{f}^{*} \\
& \bar{C}=\bar{r} \bar{B}+\left(\frac{1-\tau}{\tau}\right) \bar{G} \\
& \bar{r}=\frac{1-\delta}{\delta} \\
& \frac{\bar{M}}{\bar{p}}=\theta \bar{C}\left(1+\frac{1+\bar{r}}{\bar{r}}\right) \\
& \bar{H}_{d}+\bar{H}_{d}^{f}=\bar{H} \\
& \bar{H}_{d}=k \alpha\left(\bar{n}+\bar{n}_{f}\right)^{-\frac{\alpha}{\beta}+\alpha-1} \bar{q}^{\alpha-1} \bar{w}_{m}^{1-\alpha} \bar{X}
\end{aligned}
$$

